\title{
Bir Taşra Şehrinin Sözcülüğünü Yapmak: Fikret Otyam ve Urfa $(1953-1993)^{1}$
}

\author{
ibrahim Halil TANIK, Serkan ŞENEL ${ }^{2}$
}

Bir Taşra Şehrinin Sözcülüğünü Yapmak: Fikret Otyam ve Urfa
(1953-1993)
Özet

Bu çalışmada bir şehir ve bir insan arasındaki yaklaşık 40 yıllık bir hikâye incelenmiştir. 1953'te Urfa ile tanışan Otyam, vefatına kadar şehirle bağını kesmemiş, sürekli ziyaretlerde bulunmuş ve gözlemlerini eserlerine yansıtmıştır. Bunlar, bölge halkının fizikî özellikleri, giyim-kuşamı, müzik kültürü, bölgenin siyasal ve sosyal şartları, sağlık ve ulaşım sorunları olarak Otyam'ın eserlerinde yer bulmuştur. Bölgenin zengin toprak yapısına rağmen, sulama imkânının olmayışından dolayı yaşadığı olumsuzluklara ilişkin baraj yapılması için çaba göstermiştir. Bu çalışmada Otyam'ın kendi eserleri incelenmiş, ayrıca arşiv belgeleri, gazeteler ve diğer araştırma eserlerden yararlanılarak Urfa ve Otyam arasında 40 yıl gibi uzun süreye uzanan bu özel bağ konu edinilmiştir. Böylece Cumhuriyet döneminde Urfa'ya dair sosyo-ekonomik ve sosyo-kültürel bir bakış açısını Otyam'ın penceresinden sunmak mümkün olmuştur.
Being A Spokesperson For A Provıncial City: Fikret Otyam And Urfa (1953-1993)

\section{Abstract}

In this study, a 40-year-old story between a city and a person was examined. Otyam, who met Urfa in 1953, did not cut his ties with the city until his death, made constant visits and reflected his observations on his works. These were found in Otyam's works as the physical characteristics of the people of the region, clothing, and music culture, political and social conditions of the region, health and transportation problems. Despite the rich soil structure of the region, the negativities experienced due to the lack of irrigation facilities, so he made an effort to build a dam. In this research, Otyam's own works were examined, and this special bond between Urfa and Otyam, which stretched for 40 years, was discussed by making use of archive documents, newspapers and other research works. Thus, it was possible to present a socio-economic and socio-cultural perspective on Urfa in the Republican period from the eyes of Otyam.

Keywords: Fikret Otyam, Urfa, Harran, Atatürk Dam.

Paper Type: Research

Makale Türü: Araştırma

\section{Giriş}

Bazı şehirler, ziyaretçilerini kendine hayran bırakırlar. Tabi ki bunda, şehrin kültürel ve sosyal zenginliğinin olması önemlidir. Bundan başka, o şehrin insanlarının misafirperverliği ve samimi tutumu, ziyaretçilerin hayranlığını arttırmaktadır. Ziyaretçiler de merak duyduğu bölgelere gitmek için sebepleri değerlendirirler. Gitmek istedikleri bölgelerin tarihî arka planından başka, bölgenin sorunlarını dert edinirler. İşte bu şehirlerden birisi de Urfa, şehrin müdavimi ise Fikret Otyam'dır.

Fikret Otyam, 19 Aralık 1926 tarihinde Aksaray'da doğmuştur (TRT Geçmişten Geleceğe Bilgiler Belgeler Cilt: III, 1997: 1007). Babası önceleri asker daha sonraları da eczacı olan Vasıf İbrahim Efendi, annesi ise Naciye Hanım'dır (Otyam, 1981: 6). Babası Vasıf Bey Yemen' de ve Milli Mücadele yıllarında silahaltında bulunduktan sonra, emekli olmuştur. Askerlik hayatında İsmet İnönü ile görev yapmıştır. Askerî görevinden sonra eczacılıkla meşgul olmuştur. Fikret Otyam babasının komutanı İsmet İnönü ile tanışmasını şöyle açıklamıştır; “24 Temmuz 1942, Reisicumhur Ismet Paşa, Adana'dan Ankara'ya geçerken öğle yemeğini bizim evde yedi. Illk kez Paşa’nın fotoğrafını o gün çektim. Nereden, nasıl bilebilirdim ölünceye kadar fotoğraflarını çekeceğimi."

\footnotetext{
${ }^{1}$ Bu çalışma, 6-8 Nisan 2018 tarihleri arasında gerçekleştirilen III. Uluslararası Osmanlı Sancağından Cumhuriyet Kentine Urfa Tarihi sempozyumunda sözlü sunulan bildirinin gözden geçirilmiş ve genişletilmiş halidir

2 Ibrahim Halil Tanık, Dr. Öğr. Üyesi, Harran Üniversitesi, Tarih Bölümü, ihaliltanik@harran.edu.tr, https://orcid.org/0000-00031614-3279, Serkan Şenel, Arş. Gör. Harran Üniversitesi, Tarih Bölümü, serkansenel@harran.edu.tr, https://orcid.org/0000-00027219-4057
} 
İbrahim Halil TANIK | Serkan ŞENEL

Otyam, ilk ve orta öğretimini Aksaray'da tamamlamıştır. Ortaokuldayken Fransızca öğretmeni olan Emekli Albay Lüleci Haşim Bey fotoğraf makinesini ona hediye etmiş ve onun resim ve fotoğraf tutkusu da bu şekilde başlamıştır. Illk sergisini ise Aksaray Halkevi'nde açmıştır (Çakırbaş ve Gönen, 2021: 70). Lise eğitimini kesintili olarak sürdürmüş, Ankara ve Kayseri'de öğrenim görmüştür. Liseden sonra İstanbul'a gelerek Devlet Güzel Sanatlar Akademisi Yüksek Orta Resim Bölümü'nde eğitime başlamış ve 1953'te yükseköğretimden mezun olmuştur. Akademi hayatında Bedri Rahmi Eyüboğlu ile birlikte çalışmıştır. Üniversite yıllarında gazeteciliğe de başlamıştır. 1950'de Cihad Baban ve Ziyyad Ebuziya'nın Son Saat gazetesine ilgi göstermiştir. 58 yıl devam edeceği gazeteciliğe 1950' de "Son Saat" gazetesinde başlamış ve ömrü boyunca bu mesleğe devam etmiştir. 1953'te Falih Rıfkı Atay'ın "Dünya" gazetesinde Yazı İşleri Müdürü Ali İhsan Göğüş'ün yardımcısı ve yazarı olmuştur. "Son Saat" gazetesinde başladığı gazeteciliğini "Dünya" ve "Ulus" gazetelerinde devam ettirmiş, sonra uzun yıllar Cumhuriyet gazetesinde köşe yazarlı̆ı yapmış, 1953'te evlenmiştir. Askerlikteki ilk görev yeri Polatlı olup, sonra Ankara'da Bando Mızıka Hazırlama Ortaokulu'nda resim öğretmenliği yapmıştır. Gazete sayfalarına taşıdığı röportajlarını fotoğraflarıyla da desteklemiştir. 1979'da gazeteden emekli olmuş, Antalya'ya yerleşerek resim çizmeye devam etmiştir. Tuvallerinde de tıpkı fotoğraf ve röportajlarında olduğu gibi Anadolu insanını konu edinmiştir. Anadolu ve Güneydoğu Anadolu ile ilgili yazdığı röportajlarla tanınmış, bu röportajlarını çok sayıda kitapta toplamıştır. Resimlerinde keçi ve başı örtülü Anadolu kadınlarını figür olarak sık sık kullanmıştır. Anadolu'yu, insanlarını, hayvanlarını, bitkilerini ve mahalli unsurlarını işlemeyi seven bir ressam olarak tanınmıştır. Resimlerinde göz figürleri üzerinde özellikle durmuş; gözleri iri ve dikkat çekici olarak işlemiştir. Ona göre "Dünyada üç tane güzel göz vardır. Birincisi; Doğu Anadolu kadını gözü, ikincisi; eşek sıpası gözü ve üçüncüsü; ceylan gözü." Ressam iri gözlü Anadolu kadınlarının resimlerini betimlerken burunları ve ağızlarını küçük çizmiştir. Anadolu'nun çeşitli yerleri, dağlar, kar altındaki köyler, genç kadınlar, onların rengârenk kıyafet ve başlıkları, soru sorar gibi izleyene kocaman bakan gözleri, dağ keçileri ve Harran Ovası, Fikret Otyam'ın en çok işlediği konulardır (Otyam, 1987: 21).

Ressam olarak birçok esere imza atan ve gazetelerde makaleler yayımlayan Otyam'ın kitapları da mevcuttur. Otyam'ın, kardeşleri de kendisi gibi sanatçı olan bir aileden gelmektedir. Besteci ve orkestra şefi Nedim Vasıf Otyam ile Nusret Kemal Otyam'ın kardeşidir. Otyam, Böbrek yetmezliği nedeniyle tedavi görmüş, 9 Ağustos 2015'te Antalya'da vefat etmiştir (https://fikretotyam.com/biyografi, Erişim Tarihi: 21.04.2021).

\section{2. Çalışmanın Yöntemi}

Çalışmamız, eserin merkezinde olan Cumhuriyet dönemi entelektüellerinden Fikret Otyam'ın bir şehirle olan ilişkisi, nitel bir araştırma yöntemi kullanılarak oluşturulmuştur. Yazar-ressam Otyam'ın bölgeyle olan bağlarının bir kısmı kendi eserlerine yansımış bir kısmı da gazete röportajları, başka çalışmaların içerisinde değerlendirilmiştir. Otyam'ı konu edinen tez çalışmaları da bunlara dâhildir. Eserin içeriği zenginleştirecek arşiv belgeleri de çalışmamızın kaynakları arasındadır. Çalışmamızda, tüm bu kaynakların içerisinde Urfa'ya dair Otyam'ın izleri yansıtılmıştır. Bazı eserler aynı yıl yayımlandığı için, olası bir karışıkığı önlemek adına küçük harflerle (a, b) kodlanmıştır. Çalışmamızda alıntı yapılırken, araştırma ve yayın etiğine uyulmuştur. 


\section{3. Çalışma Bulguları}

Tarih alanında genellikle 20. yüzyıl öncesinde "gezginlerin gözünden $x$ şehri" diye başlayan pek çok nitelikli çalışma kaleme alınmıştır. Ancak Cumhuriyet döneminde bu tür örneklere az rastlanılmaktadır. Çalışmamızın bu anlamda da literatüre katkı sunacağı kanaati, bizi teşvik eden bir diğer sebep olmuştur. Nitekim araştırmamızın bulguları da bizi doğrular niteliktedir. Şehrin özellikle sosyo-ekonomik anlamda nasıl bir süreç yaşadığı, Otyam'a müspet tepkileri ve onun da tıpkı bir şehrin ferdi gibi bölgenin geri kalmışlığını sadece yazmayla yetinmeyerek, aynı zamanda çözümü içinde gösterdiği çabalar, çalışmamızın önemli bulguları olmuştur.

\section{Fikret Otyam'ın Urfa'yla Tanışması}

Bir bölgeyi ziyaret edenlerin tek gayesi, sadece görsel amaçla gezmek değildir. Bölgenin gerçekleriyle yüz yüze gelip bunları fotoğraflayıp tanıkık etmek, ziyaretçilerin amaçları arasındadır. Bazen bunu biraz daha aşarak bölgenin sorunlarını çözme girişimleri meydana çıkar. Bu da toplumsal belgeci fotoğraf olgusunu oluşturur. Bu olguyu Urfa için oluşturanlardan birisi Fikret Otyam'dır. $\mathrm{O}$, sadece bu şehri gezmekle kalmayarak, toplumsal aksaklıkların düzeltilmesi yönünde çaba göstermiş ve toplumsal değişimi amaç edinmiştir (Oral, 2011: 22-25).

Fikret Otyam Urfa'ya ilk defa 1953 yazında gelmiştir. Bu gelişini şu şekilde anlatıyor; "1953 yılının Temmuz ayıydı, Sirkeci'den kamyona atladım. Aksaray, Adana, Gaziantep ve Birecik'in karşı yakası. Otobüs Fırat kenarında durmuştu. Tüm yolcular Fırat kenarına sebilhane ibriği gibi dizilmiştik. Gemi dedikleri sal geldi, cümbür cemaat doluştuk, Birecik kıyısına çıktık, sonra ver elini Urfa. (Otyam, 1994b: 7)" Otyam Urfa'ya giderken, Birecik'e geldiğinde 1952'de temeli atılan köprünün inşaatı (BCA, 30.11.1.0/255.4.3 Tarih: 10.01.1956) devam ediyor, henüz tamamlanmamıştı. Köprünün tamamlanması 1956 yılında gerçekleşmiştir (Akgün, 16 Nisan 1956, Sayı: 2397).

Fırat'ın karşı tarafa geçmek isteyenler pek güvenli olmayan taşıtları kullanmak zorunda kalmışlardır. İnsanlar, eşyalar, araçlar ve hayvanlar hepsi aynı gemide taşınmıştır. Gemi çalışanları uzun sırıklarla dört köşe olan gemiye benzeyen aracı iterek karşı tarafa geçişi sağlamışlardır. Bu yöntemle karşı tarafa geçen Otyam, Urfa'ya ulaştığında Urfa Palas Oteli'nin ikinci katına yerleşmiş, ardından şehrin önemli mekânlarını ziyaret etmeye başlamıştır. İlk uğrak yeri faytonla gittiği Balıklıgöl olmuştur. Halilürrahman camisinin mimarisi, dikkatini çeken yapılar arasında yer almıştır (Otyam, 1994b: 19). Otyam buna dair anısını şu şekilde ifade etmiştir; "Ağzım açık bakıyorum bu mimari şaheserine. Bir park var, içinde kocaman kocaman balıkların gezindiği alamet bir havuz. Sonradan öğreniyorum, havuzdaki su neredeyse açık kapalı kanallarla, Urfa'yı dolanırmış." (Otyam, 1994a: 5.)

Tarihi mekânların sözlü anlatımı, bölgenin daha tanıtılmasında önemli bir yer tutar. Günümüzde olduğu gibi, 1950'lerde Balıklıgöl'de rehber hizmeti sunan kimselere mevcuttu. Otyam da Hurşit Hoca namındaki bir kişiyle tanışmış ve ondan $\mathrm{Hz}$. ibrahim'in ateşe atılması ve Balıklıgöl hakkında bilgi almıştır (Otyam, 1994b: 20). Kitapla ilgili Sami Barlas, onun Urfa'da tanıştığı diğer isimlerden birisi olmuştur. Onun işyerinde köşe yazarı olan emekli öğretmen Hulusi Kılıçaslan'la tanışmışır. Bu iki isimden Urfa'nın tarihi ve kültürü hakkında bilgi almıştır (Otyam, 1994b: 25). Otyam böylece bir an önce şehri tanımaya çalışmışır. Bu süreçte şehrin okuryazarlarına rastlaması, Urfa ile arasında özel bir bağ kurmasında etkili olmuştur.

\section{Fikret Otyam'ın Urfa'sında Sağlık Koşulları}

Urfa'ya ilk geldiği esnada belediye sağlık memuruyla da tanışan Otyam, onunla çocuk doğum-ölüm oranlarıyla ilgili bir mülâkat gerçekleştirmiştir. 1952 yılında 427 doğum olduğu ancak aynı yıl 466 çocuğun da öldüğü bilgisini almıştır (Otyam, 1994b: 21). Bu rakamlar il merkezinde tespit edilmiş, ilçeler ve köyler hakkında bir malumat edinememiştir. Bu dönemde doktor sıkıntısı çeken Urfa'da çocuk ve kadın doğum uzmanının olmayışı da olumsuz şartların etkisini artırmıştı. Devlet hastanesinde cerrah doktorunun sayısı ise bir ile sınırlı kalmıştır. Otyam, bu konuda Urfa milletvekillerinin şehrin sorunlarına ilgi göstermeyişini eleştirmiştir. II merkezi ve ilçeler toplam nüfusun yaklaşık 300.000 olduğu bir dönemde durumun ciddiyeti 
daha çok belirginleşmiştir (Otyam, 1994b: 22). İstatistiki bilgiler de Otyam'ın tespitlerini doğrular niteliktedir. 1960 yııında Urfa merkezde sağlık kurumunun sayısı 4, yatak kapasitesi ise 240 ile sınırlı kalmıştır (İstatistik Genel Müdürlüğü, İstatistik Yıllığı 1960-1962, 1963: 124). Şehrin hastane ve doktordan başka sağlık sorunları da mevcuttu.

Şehir merkezinde pis suların aktığı dere ve sebep olduğu hastalıklar Otyam'ın dikkatini çekmiştir. Bu olumsuz durumun neden olduğu karasinekler ve ondan bulaşan hastalıklar yaygınlaşmıştır. Özellikle sıtma hastalığından muzdarip olanların sayısı yüksek bir seviyededir. Bu hastalığa maruz kalanların vücudunun zayıf olmasına rağmen göbeklerinin çok şişkin olduğu onun şehrin sağlık koşullarını gözlemlediği noktalardan birisidir. Bundan başka trahom Urfa'da görülen yaygın hastalıklar arasındadır (BCA, 30.10.0.0./177.220.17 Tarih: 03.11.1930). 1924'ten itibaren ülke çapında, bu hastalığa karşı mücadele verilmiştir (Özer, 2014: 126-128). Hükümetin gerekli bütçe işlerini tamamlamasıyla (Tekir, 2019: 416), bir dönem kapatılan trahom hastaneleri Urfa'da 15, Siverek'te 10 yataklı olmak üzere 1933'te aktifleştirilmiştir (BCA, 30.18.1.2/33.7.011, Tarih: 18.01.1933). Uzun bir dönem etkisini gösteren bu hastalığın yaygın olduğu ve Otyam'ın Urfa'yı ziyaret ettiği yıllarda sadece bir göz doktoru vardı (Urfanınsesi, 17 Nisan 1953, Sayı: 182).

\section{Fikret Otyam'ın Ceylanpınar'a Dair İzlenimleri}

Urfa merkezde birtakım gözlemler yaptıktan sonra Otyam Ceylanpınar ilçesine gitmiştir. Burada halkın geçim sorunları dikkatini çekmiş ve Ceylanpınarlılarla birtakım görüşmeler yaparak, bölgenin koşullarını kayıt altına almıştır. İşsizliğin yoğun olduğu bölgede, kaçakçılık adeta geçım kapısı olmuştur. Ancak bu tür girişimler bazen ciddi yaralanma ve hatta ölümle sonuçlanmıştır. Bir anne ile oğlunun ölümüyle sonuçlanan bir olay hakkında mülakat yapmıştır. Sınırda görev yapan askerlerle ikili ilişkileri gelişen oğul, kaçakçılık yapmak için anlaşmıştı. Ancak kaçakçıı esnasında oğlu ve başka bir kişi, askerler tarafından sınır ihlali sebebiyle vurularak hayatını kaybetmiştir. Bölgenin en gerçek sorunlarına dikkat çeken Otyam, özellikle verimli toprakların susuzluk sebebiyle işlenemeyişini, gözyaşının en büyük etkeni olarak görmüştür. Kaçakçılık ve bu tür acıların, bunun bir sonucu olduğu yazılarına yansımıştır (Otyam, 1994b: 24).

Otyam'ın üzerinde durduğu kaçakçılık ve bundan kaynaklanan acıların başka örneklerini de kaleme almıştır, başka bir ailenin de benzer acısına şahit olmuştur. Suriye sınırında olan Ceylanpınar'da sınırın diğer tarafına geçişler tehlikeli olmuştur. Kaçakçılıkla ya da başka pek çok amaçla sınır ihlalleri gerçekleşmiştir. Bu ihlallerin sebeplerinden birisi de halkın, Suriye'deki akrabalarıyla gerçekleştirdiği ziyaretlerdir. Anne, eşi ve oğlu bayram ziyareti için sınırın karşı tarafına yani Suriye'ye geçmek ve annenin kız kardeşini ziyaret etmek için gitmek istemişlerdir. Nöbetçi askerlere öncesinde bunu bildirmişler ancak buna rağmen, gece saatlerinde sınıra geldiğinde askerler tarafından açılan ateş sonucu o annenin de oğlu hayatını kaybetmiştir (Otyam, 1994c: 16-18). Otyam'ın derinden etkilendiği bu iki olayın, başka örnekleri de mevcuttur.

\section{Fikret Otyam'ın Urfa'da Sosyoekonomik Gelişmelere Dair Gözlemleri}

Urfa ekonomisinin tarıma dayalı olduğunu kaydeden Otyam, bu konuda Harranlılarla pek çok mülakat yapmıştır. Ona göre buradaki çiftçilerin en önemli sorunu Harran Ovası'nın sulanamaması olmuştur (Dindarzade, 2015: 8). Bundan başka, ikinci sorun ise toprak ağalarının tahakkümünden kaynaklanmıştır (Otyam, 1994b: 22). Sulanabilir arazilerin tek elde bulunması, bireysel zenginleşmenin önünü tıkadığı gibi, halkın devlet otoritesine olan bağılı̆̆ını da azaltımıştır. Çok partili hayatın başlamasıyla, Marshall Yardımı doğrultusunda Urfa'ya gelen traktörlerin yedek parça temini ve tamir imkânının bulunmayışı bölge ekonomisini engelleyen diğer bir sorun olmuştur (Otyam, 1994b: 22). 1961'de Urfa'da sadece 584 adet traktör vardı (IGM, İstatistik Yıllığı 1960-1962, 1963: 234.) ve şehirde tamir ve yedek parça sorunları çözülemediğinden çoğu zaman Gaziantep gibi yakın illere gitmek zorunda kalınmıştır. Bunu önlemek için sık sık ilgili kurumlar traktör kullanım ve tamiri için kurslar düzenlemiştir (Demokrat, 13 Ocak 1953, Sayı: 17).

Otyam'ın Urfa'da sürekli karşılaştığı ve eleştirdiği sorunlardan birisi toprak ağalığı ve köylünün kendi refahını yükseltememesidir. Bu konuyla alakalı şehirde ilk tecrübesi ise kayda değerdir. Falih Rıfkı Atay'ın sahibi olduğu Dünya gazetesinde çalışan Otyam, Atay'ın TBMM'den arkadaşı Urfa eski milletvekiline mektubunu vermek için mağazasına gitmiştir. Onunla sohbete başlayan Otyam, halkın sorunlarını özellikle de 
toprak ağalarından serzenişlerini dile getirmeye başlamıştır. Ardından bölgede inceleme yapmak üzere ondan yardım ismiş, o da bir personelini bu iş için görevlendirmiştir. Köylerde geziye başlayan Otyam, personelin "bu köy de ağamızın, şu köy de ağamızın" sözleri üzerine "ağanız kim?" diye sormuştur. Az önce konuştuğu kişinin olduğu cevabını almıştır. Bu cevap onu çok şaşırtmış; çünkü az önce onun yanında topraksız köylülerin müsebbibi olarak ağalarını göstermiş ve kendi tabiriyle "baltayı taşa vurmuştu". Bu andan itibaren konuşmalarına daha dikkat edeceğini ifade etmiştir (Otyam, 1994b: 23).

Ağalık tahakkümü eleştirisinden başka, köylülerin toprak sahibi olmaları ona göre bütün sorunları çözmemiştir. Harran Ovası'nın susuz olmasından dolayı ekinler son aşamaya gelemeden aşııı sıcaklarda zarar görebiliyordu. Yağışın az olduğu yıllarda kurakıık kendini daha iyice hissettirmiş, tahribat daha da artmıştı (Otyam, 1994a: 19). Bu arada ekin için bankadan alınan kredilerin zamanında ödenmemesinden dolayı pek çok köylü icralık olması Otyam'ın gözlemleri arasındadır. Bazen bu borçları ödemek için çiftçiler topraklarını satmak zorunda kalmıştır. Ayrıca Suriye üzerinden gelen çekirge sürüleri, Harranlı çiftçilerin ekinlerine zarar veren diğer bir unsur olmuştur (Otyam, 1994b: 43). Urfa ve civarında çekirge istilasına karşı mücadele 1920'lerden itibaren (BCA, 30.10.0.0./185.277.1 Tarih: 05.04.1923) başlasa da 1950'lere kadar, çiftçilerin zarar vermeye devam etmiştir.

Köy ekonomisinden başka Otyam Urfa'da bulunduğu sırada valinin çarşı denetimine şahit olmuştur. Bu esnada valinin fiyatları kontrolü ve bazı keyfi uygulamalarını kaydetmiştir. Otoritenin halka karşı sert tutumlarını eleştirmiştir (Otyam, 1994b: 33). Bu tür eleştirilerle beraber, dönemin yaygın sorunlarından birisi olan kaçak ürünler teftişler sonucu tespit edilmiştir (Demokrat Urfa, 21 Şubat 1958, Sayı: 859).

Otyam, şehrin gelişimini engelleyen hususlardan birisi olarak yolsuzluğu ve psikolojik şiddeti belirtmiştir. Urfa'da yaşanan hazin bir olay, onun dikkatini çekmiştir. 21 Mayıs 1967 tarihinde intihar eden Viranşehir Kaymakamı Doğan Gürbüztürk Otyam'ı derinden etkilemişti. Otyam bu olayı biraz daha detaylı incelemek için kaymakamın vefatından sonra Urfa'ya gelmiştir. Olay resmî kayıtlarda ailevi bir sorun olarak kaydedilmişti. Cumhuriyet Senatosu Urfa üyesi İbrahim Etem Karakapıcı'nın olayla ilgili sorusuna dönemin İ̧̧şleri Bakanı Faruk Sükan yolsuzluktan çok ailevi sebeplerle intiharın gerçekleştiğini ve savcılı̆ın takipsizlik kararını açıklamıştı (TBMM Zabıt Cerideleri, Cumhuriyet Senatosu Tutanak Dergisi, 1968: 19). Bu cevap Otyam'ı ikna etmemişti. Bölgede yaptığı röportajlar neticesinde, ailevi sorunlarının aslında gerçek olduğunu ancak bölgede pek çok usulsüzlüğün yaşandığını kaydetmişti. Kamu arazilerinin usulsüz olarak dağıtılması, kiralanması, Ceylanpınar Çiftliği arazilerinden haksız gelir elde edenleri yazmıştır. Bunlardan başka rüşvet olaylarına da çokça maruz kalan kaymakamın ruh halinin iyi olmadığını, dinlediklerinden rapor etmiştir. Kaymakam vefat ettiğinde Viranşehirliler ağıtlar yakmışlar ve Otyam'a ilettikleri tabirle "Kaymakam Babo" artık aralarından ayrılmıştı (Otyam, 1969b: 49-110).

Uzun süre şehre gelmediğinde Harran'ı çok özleyen Otyam, helikopterle bir gezi düzenlemiştir. Pek çok fotoğraf çekmiş; ancak istediği kadar geniş bir gözlem yapamamıştır. Urfa valiliğinden bir uçak gezisi rica etmişti. Dönemin Vali yardımcısı Hasan Duruer (1991-1997) onun ricasını yerine getirmiş, bir tarım uçağı (Otyam, 1991a: 8) filosu oluşturan Celal Özdilek'in uçağı tahsis edilmişti (Otyam, 1994b: 88). Uçakla şehrin güney sınırlarını gezmişlerdi. Otyam'ın dikkatini çeken en önemli hususlar, yine susuz topraklar ve mayınlı sınır bölgeleri olmuştur (Otyam, 1994b: 88). Bölgenin tarıma elverişli olmamasını Harranlıları Çukurova bölgesine mevsimlik iş̧̧i olarak çalışmaya iten en büyük sebep olarak görmüştür (Otyam, 1994b: 93).

Otyam'ın Urfa'da ilk pastanecilikle ilgili bir anısını vardır. Urfa'da belediye başkanlığını yapmı̧ Ömer Alay, İstanbul'dan pastane kültürünü şehre taşımış ve ilk pastaneyi kendisi açılmışır. Urfa'nın yöresel tatlılarının yanında, muhallebi gibi başka tatılıar da üretilmeye başlanmış̧ır. Sekizinci dönem Urfa Milletvekili Atalay Akan da bu pastaneye uğramıştı. Otyam, Urfalıların pastaneye gitmeye çekindiklerini, bir şeyler yerken başkalarının görmesinin ayıp karşılandığını yazmıştır (Otyam, 1994b: 103). Şehrin görgü kurallarını izah eden bu gözlemi önemli bir değerdir.

Otyam ve eşi Filiz Hanım 1953'ten sonra 40 yılın ardından Urfa'ya birlikte gelmişlerdi (Otyam, 1994b: 79). Otyam çiftinin ilk işi Hanelbağrur'a gitmek olmuştu. Illk geldiğinde 27 yaşında olan Otyam (Otyam, 1994a: 19), bu defa 67 yaşındaydı. Hanelbağrur köyüne elektrik ve telefon gelmişti ama henüz suya kavuşa- 
mamıştı. Toplam 7 haneli köyde 8 erkek, 8 kadın ve çocuklar vardı. Çat kapı bir eve giren Otyam, ev sahipleriyle mülakata başlamıştı (Otyam, 1994b: 81). Ardından Tüccari köyüne giden Otyam, dikiş-nakış kursunu bitiren kızların elişi sergisini gezmişti (Otyam, 1994b: 82). Köydeki teknolojik gelişmeleri kaydeden Otyam, Ali Erkılıç adında bir köylüye konuk olmuştur. Onunla sohbetten sonra Halil Tilki adında bir Urfalı davet etmiştir. Onun bir gazeteci olduğunu anlayan ev sahibi, devlet büyüklerine köyün sorunlarını iletmesi için onu aracı görmüş, çözüm isteklerini iletmesini istemiştir (Otyam, 1994b: 84).

Şehir insanı, Otyam'ı seslerini Ankara'ya ulaştırmak için bir köprü olarak görmüşlerdi. Bu konuda gösterilebilecek güzel bir örnek ise, Otyam'ın İsmet İnönü ile görüşmesidir. Doğu gezilerinin ardından İsmet İnönü ile görüşen Otyam, çektiği fotoğrafları ve kayıtları İnönü’ye sunmuştu. Bu arada görüşmelerinde babasıyla olan hukukundan hiç bahsetmemişti. 1962'de Pembe Köşk'te İnönü ile görüşen Otyam, ona bölgenin acilen kalkındırılması ve askerî darbenin ardından devlete olan güvenin tesis edilmesi gibi fikirlerini söylemiştir (Otyam, 1994b: 69). Toprağı, hayvanı olmayan ve geçim sıkıntısı çeken köylüler ekseriyetle meşgul oldukları iş sahası, şehirlerarası nakliye sektörüydü. Ancak bölgedeki ve Irak'taki siyasi huzursuzluklar sebebiyle Habur sınır kapısının kapanmasının ardından (Beceren-Koç, 2016: 90), köylüler hem borçlu kalmış hem de geçimi sağlama noktasında sorunları artmıştır (Otyam, 1994b: 87).

\section{Fikret Otyam ve Urfa'da Tarihî Doku}

Otyam’a göre, 1957-1959 yılları arasında valilik yapan Kadri Erdoğan, birçok olumlu çalışması yanında tarihî ve mimarî dokuyu bozarak yeni caddeler açan ikinci vali olmuştur. Erdoğan'ın Kara Meydanı civarından başlayarak Haşimiye Meydanı'na kadar yaptığı yol genişletme çalışmalarında Avşaroğullan evi, Sarraç Salih Efendi evi, Kaplamaların evi, Eski Paşa (Yıldız) Hamamı ve Kunduracı Pazarında Ağanlar'a ait evler başta olmak üzere birçok mimari eser yıkılmışı. Aynı yıllarda, Balıklıgöl'ün güney kenarında yer alan ve birer yapı güzelliğinde olan tarihi evler de ortadan kaldırılmışı. 1971-1972 yıllarında Belediye tarafından Balıklıgöl'ün kuzeyindeki tarihi Molla Ali sokağında çok sayıda güzel evler yıkılarak Vali Fuat Bey Caddesi'ni Halepli Bahçe'ye bağlayan çok kısa ve gereksiz bir yol açıımıştı. Belediye 1976'da yollar için pek çok binayı yıkmış, 1978 ve 1979 yıllarında da devam etmişti. Üstelik bu yıkılan evlerin içinde tescilli olmasına karşın kurtarılamayan 8-10 ev de vardı. Bu yolun açılmasını, yerel yönetimin iktidardaki darbe iradesine yakınlaşma aracı olarak görmüş ve 12 Eylül Caddesi ile ilgili anısını da bu şekilde ifade etmiştir. Halepli Bahçe ve yakın çevresi sit alanı kabul edilmişti. Tarihî değeri olan mozaikler ve fresklerle süslü yüzlerce antik kaya gecekonduların altında kalmıştı. Tarihî değerlere önem verilmemesini Otyam şu şekilde eleştirmiştir: "Bilgisizliğin, yoksulluğun, ucuz politikanın gözü kör olsun desek bir işe yarar mı? Yaramaz! (Otyam, 1994b: 35-36)" Otyam'ın önem verdiği kaya mezarları sonraları koruma altına alınarak, gecekondulardan arındııımıştır.

Urfa'nın evleri kadar mezarlıkları da Otyam'ın dikkatini çekmiştir. Taş ustalığı ve taşların üzerindeki yazılar hafızasında yer edinmiştir. Eski Urfa evlerinde yaşamak isteği onda hep canlı kalmıştı. Bu evlerin yok oluşu onu çok hüzünlendirmişti. O dönemde Cihat Kürkçüoğlu'nun, "Ruha'dan Urfa'ya (1780 -1980)" adlı kitabını inceleyerek şunları aktarmışır:

“...Giriş bölümüne acıyla ve özetle bir göz atalım bakalım: Şanlıurfa'da yakın tarihimizde modern anlamdaki ilk imar hareketi 1903 yıllarında mutasarrıfık yapan Ethem Bey zamanında başlamıştır. ...Ethem Bey'in Urfa'nın eski mimarisini olduğu gibi koruyarak gelişmeyi kuzeye doğru kaydırma fikrini mutasarrıf Nusret Bey de benimseyerek imar çalışmalarını bu yöne doğru geliştirmiştir. Nusret Bey 1917 yılında Hacı Kamil köprüsünü kuzeye doğru bağlayan Mustafa Kemal Paşa Caddesi'ni açarak ortasını çiçeklerle donatmış ve bu cadde üzerine Mustafa Kemal Paşa Anıt Çeşmesi (Yol Gösteren Çeşmesi) ve Harb-i Umumi Şehitleri Abidesi'ni yaptırmıştır. 1924 -1928 yılları arasında Urfa Valiliği yapan Fuat Bey'in Balıkıgöl'den Samsat Kapısı'na giden yolu açması tarihi kenti bozan ilk imar hareketi sayılır." (Otyam, 1994b: 37)

24 Mayıs 1993'te Balıklıgöl'deki çevre düzenlemelerine şahit olan Otyam, uygulanacak projeyi beğenmediğini yazmıştır. Rızvaniye Camisine çok hayran kalmış ve bu yapının da tahrip edileceğinden endişelenmiştir. Vali Fuat Bey Caddesi'nde 104 yıllık bir eve ayrı bir ilgi göstermiştir. Evde bulunan haremlik, selamlık, kiler, tandırlık, kuş yuvaları, havuzlu hayatı hayranlığı artmış ve "keşke böyle bir evde doğsaydım" demiştir. Bu evi valilik restore etmiş, açılışı dönemin Devlet Bakanı Necmettin Cevheri'nin katılımıyla gerçekleşmiştir. Cevheri şehrin konukseverliğini şu şekilde ifade etmiştir: "Burada Urfa sevdalıları varken (Fikret Otyam ve 
Behruz Çinici) kurdeleyi kesmek bana düşmez" demiş ve kırmızı kurdeleyi Otyam, beyaz kurdeleyi de Çinici kesmiştir (Otyam, 1994b: 104). ilaveten, Urfa'da pek çok tarihi mekânı gezen okurlarına sürekli bu bölgeyi görmelerini, Urfalıların samimiyetini yaşamalarını ve yöresel yemeklerini tatmalarını tavsiye etmiştir (Otyam, 1994b: 50-52).

\section{Fikret Otyam'ın ve Urfa'da Eğitim}

Urfa'da bulunduğu dönemde Otyam'la görüşen şehir halkı, okulların az olmasından dolayı okuryazar oranının az oluşundan ve bu nedenden kaynaklanan geri kalmışıktan bahsetmiş̧ir. Eğitim alanındaki yetersizlikten dolayı, ekseriyetle askerde Türkçeyi öğrendiklerini, askerden sonra zamanla unuttuklarını aktarmışlardır. Bir Urfalının başından geçen olayla ilgili mülakatında Otyam şunları kaydetmiştir: "ikinci Dünya savaşından sonraki süreçte topraklarını ağaya kaptırdığı için Iran'a gider, ardından iran kolluk kuvvetlerince yakalanır. Casus olduğundan şüphelenilen Urfalı, Türkiye ile yazışmaya başlar, sonunda niyetinin para kazanmak için Iran'a gelmek olduğu anlaşıldığında hakkında verilen idam hükmü kaldırılıp Türkiye'ye iade edilir. ibrahim'in kendini ifade edememesi, gerçeğin daha geç anlaşılmasına sebep olur" (Otyam, 1994b: 41-42). Urfa'dan İran'a uzanan bu hikâyede şehrin eksiklilerini ortaya koyması bakımından önemlidir. Nitekim bu ağır şartların oluşturduğu boşluk, dışarıya göçün önemli bir etkenidir.

\section{Fikret Otyam ve Urfa Türküleri}

Urfa'nın müzik kültürüne merak salan Otyam, Urfa hoyratı için “Urfalılar bütün hıncını hoyrat söyleyerek türkülerden alıyorlar, dertlerini türkülerle yansıtıyorlar" demiştir (Otyam, 1957: 19). Urfa'da bulunduğu süreçte müzisyen İsa Barak'la tanışmışır. Urfa Musiki Cemiyet'inde Mahmut Güzelgöz ve diğerlerini dinleyip kayıt altına almıştır. Bundan başka Aziz Çekirge'nin saz yapımına şahit olmuştur (Otyam, 1994b: 57-59). Otyam, anılarını şöyle dile getirmiştir: "isa Barak dosta haber saldım, geldi. Isa Barak, Urfa oyunlarını en has oynayanlardan. Öylesine içten candan oynar Urfa oyunlarını, diyar-ı gurbette de oynayıp madalyalar almıştır. Sami Barlas'ın dükkânına uğrayıp o güzelim demli çayları içerken Hulusi Kılıçaslan da geliyor, sohbetin gözüne gözüne vuruyoruz, Urfa tarihinden, folklorundan, gelenek göreneklerinden, zulümden, siyasetten, çiğköfteye kadar ve de ünlü Urfa yağı, baklavasına, künefesine..." (Otyam, 1994a: 18). Bu gelişme, Otyam'ın şehir ve şehirlilerle kaynaştı̆̆ını gösteren bir örnek olmuştur.

\section{27 Mayıs 1960 Darbesi Sürecinde Otyam'ın Urfa Hatırası}

Dünya gazetesinin ardından Ulus gazetesine yazmaya başlayan Otyam, 1959'da açılan bir davada yargı-

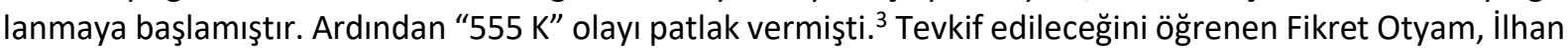
Başgöz ${ }^{4}$ ile beraber Adana ve Kilis üzerinden Urfa'ya gelmiştir (Otyam, 1994b: 30). Ceylanpınar'a geçen ikilinin amacı saklanmaktır (Otyam, 1994b: 31). Ancak 27 Mayıs 1960 askerî darbesinin gerçekleşmesiyle, saklanmaktan vazgeçip tekrar Ankara'ya dönmüşlerdi (Boybeyi, 2008: 286). Otyam ve Başgöz Urfa'dan yola çıkıp Gaziantep'te Nakıp Ağa'nın otelinde konakladıktan sonra Otyam Aksaray'a uğramıştı. Memleketi ziyaretin ardından Ankara'ya gittiler. İkilinin sığınabilecek bir yer olarak Urfa'yı seçmeleri, aralarındaki bă̆ı gösteren güzel bir örnektir. Onun, Urfa'da kaydettiği Türkçe, Kürtçe ve Arapça türküleri 27 Mayıs'tan sonra Cemal Gürsel'e Ankara radyosundan yayımlama teklifine Gürsel, “...ne sen söylemiş ol, ne de ben duymuş olayım..." diyerek reddetmiştir (Otyam, 1994b: 60). Onun darbe dönemde dahi bölgenin samimiyetini, kültürünü tanıtma çabası, kurduğu bağın örneklerinden birisi olmuştur.

\section{Otyam'ın Kısas Köyü Hatırası}

Urfa Kısas köyünde özel anıları olan Otyam, arkadaşı Fikret Turgut Sayın Urfa Valisi olunca özellikle bu köyün yolunun ve okulunun yapılması için çaba göstermiştir. 1971-1975 yılları arası vali olan Sayın, arkadaşı

\footnotetext{
${ }^{3} 27$ Mayıs 1960 darbesi öncesi, Demokrat Parti'yi protesto etmek amacıyla, 5'inci ayın 5'inde, saat 5'te Kızılay'da yapılacak mitingin parolası olarak belirlenmiştir. Elif Aktaş, "27 Mayıs Darbesi Sürecinde Ankara Olaylarından İki Kesit: 29 Nisan ve 555k", Ağrı Ibrahim Çeçen Üniversitesi, Sosyal Bilimler Enstitüsü Dergisi, 2020, 6 (2), s. 234

${ }^{4}$ Türk halk bilimci Prof. Dr. İlhan Başgöz, 13 Nisan 2021 tarihinde vefat etmiştir. https://www.aa.com.tr/tr/turkiye/turk-halk-bilimci-prof-drilhan-basgoz-vefat-etti/2208083 Erişim Tarihi: 22.04.2021
} 
Otyam'ın isteğini yerine getirmiştir. Burada özel anısının olmasının sebebi, Alevi ve Sünnilerin birlikte huzur içinde yaşaması, kendisine olan samimiyetten kaynaklı "Fikret" isminin yeni doğan bebeklere verilmesi ve bir Kısaslı'nın Otyam'ı her gezisinde misafir edişiydi. Misafir olduğu evin oğlu da ona yakınlık hissederek, resim yapmaya ilgi göstermişti. Ancak bir köylüsü ile olan husumetten sonra katil olup cezaevine girmişti. Cezaevindeyken resim yapmaya daha çok merak salan evin oğlu bu işi profesyonel olarak yapmaya başlamış, maddi gelir elde etmeyi başarmıştı. Oğlunun bir mektubunu babası, Otyam'la paylaşmıştı. Mektupta “...keşke elime yıllar önce silah yerine fırça alsaydım” demişti. Oğlu, afla cezaevinden çıkıp, Gaziantep'e yerleşmiş ve Otyam'la yeniden temas kurmuştu. Bu onu çok sevindirmişti ama husumetli köylüleri onu burada yakalayıp öldürmüşlerdi. Bu hadise, Kısas'ı ve Urfa'yı Otyam için ayrı bir önemli kılmıştır (Otyam, 1994b: 72).

\section{Fikret Otyam ve GAP}

Atatürk Barajı́nın (BCA, 30.18.1.2/401.131.8.4 Tarih: 20.07.1980.) 1980'de ihale süreci başlatılmış, şehir ve Otyam için büyük bir öneme sahip olmuştur. Barajın temel atma töreninde bulunan Otyam için, açıllşında da bulunmak onur verici olmuştur (Otyam, 1991b: 104). Bu barajın yapımıyla pek çok bölgenin sulanacağı onu umutlandıran bir gerçek olmuştu (Otyam, 1966: 69). 1992 yılında ilk açılışında Süleyman Demirel Başbakan, Turgut Özal ise Cumhurbaşkanı'ydı. Otyam, Demirel'in açılışa özel konuğu olarak onun için özel bir yeri olan şehre gelmiştir. Bu açılıştan sonra 1 Aralık 1993'te barajın tüm üniteleri faaliyete girmiştir. 23 Mayıs 1993 tarihinde Otyam, Cumhurbaşkanlığı uçağı ile gelmiştir. Bu defa Birecik Barajı'nın temel atma töreni için şehre gelmiştir. Otyam daha havaalanındayken, bazı gelişmeleri görerek sevindiğini belirtmiştir. Artık tarım uçakları mevcuttu ve hemen her yönden şehir gelişmiş̧i. Birecik ve Atatürk barajları bölge halkının kalkınması bakımından onu mutlu etmiş, yapılarla alakalı bütün detayları not almıştı (Otyam, 1994b: 7476). Birecik'te temel atma töreninin ardından, birtakım törenlere katılan Demirel, Otyam'la vedalaşıp şehirden ayrılmıştır (Otyam, 1994b: 79).

GAP'ın tamamlanmasıyla ümitlenen Otyam şunları dile getirmişti:

“...Güneydoğu Anadolu Projesi'nin (GAP) ilk meyveleri alınmaya başladığından beri benim Harran resimlerimde antenler, çanak antenleri var. Çünkü Atatürk Barajı'nda, Keban'da elektrik üretilmeye başlanmasıyla Harran evlerine elektrik gelmeye başladı. Simdi Harran evlerinde vantilatörler, Japon malı airconditionlar (klima) var. Evlerinin içinde elektrikli yayıkla ayran yapıyorlar. Mutfaklarında buzdolabı, kapılarının önünde traktörleri var. iki yılda bir araba değiştiriyorlar. Zenginliğe, refaha doğru bir gidiş var. Bu ne propagandadır, ne de başka bir şey. Sadece gerçektir. Sanatçı da gerçekleri yansıtır. Bana her zaman neden Doğu ve Güneydoğu Anadolu'nun resmini yaptığımı soruyorlar. Çünkü en iyi burayı biliyorum. Illkbahar, yaz, sonbahar, kış hep buradaydım. Kadına gelince, Anadolu halkının çilekeşi kadınlardır. Ben onların sanatçısıyım, onların yanındayım. Ama yavaş yavaş yüzleri gülüyor. Dört ürün alıyorlar artık. Ekonomik özgürlüklerine kavuşuyorlar. Hatta erkeklerine kafa tutuyorlar..." (Tezcanoğlu, 1998: 12)

Yukarıdaki ifadelerine şunları eklemiştir;

“...Doğu, Güneydoğu insanlarının gözü, kulağı, dili olmaya çalıştım. Nerede bir acı, bir zulüm, bir tatsızlık var, hemen oraya koştum. Cumhuriyet bu konuda bana olağanüstü olanak tanımıştır. Yazmakla da yetinmedim, sonuç alıncaya kadar, üstüne gittim" Kendine özgü bir üsluba ulaşan Fikret Otyam, "Röportajımın, fotoğraflarımın resmini yapıyorum, en iyi bildiğim şeyi yapıyorum" diyor. Başka bir deyişle, Doğu ve Güneydoğu Anadolu insanlarını, doğasını, hayvanını, çiçeğini, bitkisini, yaşamını konu ediniyor. "...Bütün acılığına karşın sevgi vermeye" yönelik resimler ve "Yaptığım röportajlar, resimler, çektiğim fotoğraflar birer belge olarak kalacak; çünkü inanıyorum ki GAP, on yıl sonra değil Harran Ovası'nı, dünyanın kaderini bile değiştirecek. Dünya açlığa gidiyor. Bu Harran Ovası doyuracak aç insanları... Röportaj çok önemli... Halk kendi sesini duyuyor, kendi acısını buluyor... Bir de ben çok masrafsız bir röportajcıydım. Kamyon, eşek, ne bulursam onunla giderdim, fotoğraf çekerdim... Öyle bir sevgi halesi oluştu ki bir süre içinde... Her gün telefon, mektup... Yetiş bize diye..." (Kabacalı, 1998: 12). Şehrin sorunlarını dile getirme hususunda Otyam, katkılarını bir kez daha aktarmıştır.

Fikret Otyam'ın Süleyman Demirel ile tanışması ilginç bir şekilde gerçekleşmiştir; 
“...1961'de tanıştık. Devlet Su işleri Genel Müdürü o zamanlar. Güneydoğu ile ilgili o kadar güzel şeyler anlattı ki, gözlerim doldu. Ben de o zaman Güneydoğu röportajlarını yazıyorum. Beyefendi dedi, "sizin kitapIarınız başucumda duruyor." Sonra Adalet Partisi'nden (AP) aday oldu. AP, yüreğime, dünya görüşüme aykırı bir politika. Başbakan olduğu zaman, başının belası oldum. Gazetede nasıl ağır yazılar yazıyorum onun hakkında, dalga geçiyorum. Bir gün bir şey demiyor adam. Parlamentoda istese, milletvekilleri beni linç edecekler. Ama o, beni gördüğ̈̈ zaman elimi tutar, "Gel bakalım, seninle yürüyelim" der. Doğu röportajları yayımlandığı zaman, daha dizinin anonsları yapılırken, Türkiye sallanmaya başladı. Komutanlar, milletvekilleri Demirel'e çıkmışlar, yazıları kestirecekler. Demirel, kimin yazdığını sormuş. Otyam deyince, "O yazıyorsa doğrudur" diyor, kalkıyor ayağa, "Arkadaşlar toplantı bitmiştir" deyip gönderiyor adamları. Yüreğine girmiş, biliyor ki, bu adam yalan yazmıyor. Onu sinirlendirmek için yaptığım şeyler... Basın toplantısına teyp sokardım, sesi fazla açınca "cayk" diye bir ses çıkarıyor. Toplantının en heyecanlı yerinde açıyorum. Demirel kıpkırmızı oluyor. Fotoğraf makinesine basıp duruyorum sürekli. Böyle deli ederdim adamı. Ama Demirel, beni ele vermedi hiç. "Bahara giderim yine Güneydoğu'ya" diyor. "Sevda bu. Urfa benim sevgilim. Insan sevgilisini görmeden durur mu? Giderim, televizyonları sayarım. Kadınların gözlerine bakarım, gülüyor mu içi? Çok seviyorum o gözleri. Bir çift ceylan Demirel'in yasaklı olduğu bir dönemde Güneydoğu'yu anlatmak için bir televizyona çıktım. Demirel'in adını söylemedim, ama onu anlattım. Bir telefon, Demirel, sesi titriyor. "Yav, sen ne vefalı adammışsın yav" diyor. Bir kere de televizyonda konuşuyorum, yakın zamanda. "Ceylanları özledim" demişim. Bir telefon, yine Demirel. "Yav kardeşim, hayatında da bir kez benden bir şey iste yav" dedi. Ertesi gün kapıda iki ceylan. Atatürk Barajı'nın temeli atılıyor. Ne param var gidecek, ne yazacak gazetem var. Çok duygulandım. Demirel'e bir telgraf çekip, "Bir mala harç da benim için atın" dedim. Bir mektup gönderdi bana, GAP'ın hesabını veriyor, sayfa sayfa. Demirel, Türkiye'nin en vefalı insanıdır. Ama politik yönüne gelince, bir kitap yazarım hakkında. Ama onun GAP'a yaptığı hizmeti ben bilirim. O konuda aramıza kimse giremez." Otyam'ın resimlerinde Güneydoğulu kadınların iri gözleri yer bulmuştur. Ama Otyam, "Artık içleri biraz daha gülüyor, biraz daha ama o kadar" (Temelkuran, 1996: 6).

Otyam çifti, 20-24 Ekim 1993'te ŞURKAV'ın ${ }^{5}$ konuğu olan “Dünya Güzeli Olmalı” başlıkı bir sergi düzenlemiştir. 1994 yılında Otyam, şehirle ilgili verilerini ve eserlerini şURKAV'a bağışlamıştır. Dönemin Valisi Ziyaettin Akbulut Otyam çiftine onur ödülü vererek, mukabelede bulunmuştur (Otyam, 1994b: 111-112). Otyam'ın ardından ailesi şehirle olan ilgisini devam ettirmiştir (http://www.medyaurfa.com/gundem/otyamailesi-urfa-ile-baglantisini-koparmiyor-h45903.htm Erişim Tarihi: 02.04.2018). Harran'da Fikret Otyam'ın adının verildiği kütüphaneyi ziyaret etmiştir. 19 Nisan 2001'de açılışı yapılan kütüphanede, Vali Muzaffer Dilek, Otyam'a onur ödülü takdim etmiştir (http://bianet.org/biamag/bianet/1808-fikret-otyam-kutuphanesini-acti Erişim Tarihi: 02.04.2018.)

\section{Sonuç}

Fikret Otyam, Urfa ile gönül bağını kurmayı başaran sanatçılardan birisi olmuştur. Buna mukabil Urfalılar da ona karşı bir gönül bağı kurmuşlardır. Bunda, onun iyimser kişiliği ve bölgenin misafirperverliği etkili olmuştur. Nitekim tarihin ilk çağlarından başlayarak yakın zamana kadar, Otyam gibi bölgeye merak salan kimselerin sayısı hayli çoktur.

Şehre gelenlerin içerisinde Otyam, ayrı bir yere sahip olmuştur. Şehre geldiği ilk zamanlardan itibaren sadece turistik bir amaç edinmemiştir. Bölgenin sosyoekonomik, eğitim ve sağlık durumu onun dikkatini bu bölgeye çekmesinde etkili olmuştur. İlk geldiği dönem, Türkiye'de yeni bir siyasi sürecin yaşandığı çok partili hayata geçişin başlamasına isabet etmiştir. Artık söylemler, amaçlar ve şartlar çok değişmişti. Gelişen ülkelere nazaran Türkiye'nin ve şehrin ilerleme süreci hızlı olamamıştı. Bu sebeplerden başka bir de bölgesel sorunlar, şehrin ilerleyişini olumsuz etkilemiştir. Otyam'ın sıkıkla altını çizdiği husus, tarımsal kalkınmayla büyük hamleler yapabileceği gerçeğiydi. Şehir büyük ve verimli arazilere sahip, insan kaynağı bakımından ise pek çok şehirden üstün olmasının avantajından istifade edilmesi fikrini savunmuştur. Ancak sulama olanaklarının yetersizliği tarımsal kalkınmayı engellemiştir. Sulama sorunundan başka, kırsal otoritenin -ağala-

\footnotetext{
${ }^{5}$ Şanlıurfa İli Kültür Eğitim Sanat ve Araştırma Vakfı.
} 
rın- topraksız köylülere karşı tutumu çoğulcu gelişimi sekteye uğratmıştır. Sadece belirli bir kesim zenginleşirken halkın büyük bir kısmı yerinde saymış, fakirleşmiştir. Bu gerilemenin neticesi olarak, şehrin iş gücü ya sınır ülkeleriyle kaçakçılık yapmış ya da mevsimlik iş̧̧i olarak başka şehirlere göç etmiştir.

Topraksız köylüleri topraklandırma girişimleri de Otyam'ın şehri ziyaret ettiği dönemde çok başarılı olamamışır. Toprak alan köylüler bazen aldıkları tarım makinalarının kredilerini ödemek için; bazen de kurak geçen mevsimlerde tohum ve benzeri ihtiyaçlar ve alınan kredileri ödemek için toprak satmışlardı. Uzun vadede kârlılık olamayışı, üretimde sürekliliği olumsuz etkileyen bir diğer etken olmuştur.

Otyam gözlemlerinde, şehirde eğitim ve sağlık gibi hizmetlerde büyük eksiklikler tespit etmişti. 1952 yılında çocuk ölüm sayısı doğum sayısından daha fazla olduğu, bunlardan birisiydi. Uzman ve genel olarak doktor sayısının az oluşu, şehrin sağıık koşullarını bir kat daha zorlaştırıyordu. Okulların az olmasından dolayı erkekler askerde okuma-yazma öğrenebilmiş, kadınların büyük bir kısmı da eğitim görememişti. Eğitimsizliğin şehir halkına yaşattığı zorluklar, onun satırlarında yer bulmuştur.

Memleket sevgisinin siyasi düşüncelerinden ayrı düşünülmesi gereken Fikret Otyam'ın başta Urfa olmak üzere, Doğu Anadolu'da yaptığı çalışmalar adeta halkın yönetimden talepleri olmuştur (Buçan, 2014: 8). İşte şehirle özdeşleştiğini gösteren en güzel örneklere burada rastlamaktayız. Yakaladığı her fırsatta, İnönü, Demirel gibi siyasilerden şehir ve halkı için bir şeyler istemekle yetinmemiş, bir dönem valilik yapan arkadaşından, bir köy yolunun yapılması için girişimlerde bulunmuştur.

Otyam'ın da en büyük arzularından birisi olan Atatürk Barajı́nın tamamlanması ve susuz toprakların suya kavuşmasıyla beraber bölge halkının zenginleşmesi şehrin çehresini değiştirmiştir. Sulamanın başlamasıyla mevsimlik göçlerin sayısı azalmış, üretim miktarı artmış, bölgenin tarımsal ticaret hacmi gelişmişti. Bu ilerlemeyi görmek, Otyam'ın en büyük hayallerinden birisiydi. Barajın tamamlanmasının ardından, şehre tekrar gelen Otyam, daha önce sulama imkânı olmayan süreçte görüştüğü kişilerin yüzündeki mutluluğu görünce, uzun vadede sarf ettiği emeğin karşılığını almanın verdiği mutluluğu da kalemine yansımıştır.

\section{Araştırma Yayın Etiği Beyanı}

Bu makale için etik kurul izni alınmasına gerek yoktur.

\section{Destek Beyanı}

Bu makale herhangi bir kurum veya kuruluş tarafından desteklenmemiştir.

\section{Çıkar Beyanı}

Bu makale ile ilgili herhangi bir çıkar çatışması bulunmamaktadır.

\section{Katkı Oranları}

İbrahim Halil Tanık \%60, Serkan Şenel \%40

\section{Kaynakça}

Arşiv ve Resmi Yayınlar

Türkiye Cumhuriyeti Cumhurbaşkanlığı Devlet Arşivi Başkanlığı Cumhuriyet Arşivi (BCA)

İstatistik Genel Müdürlüğü (1963), Istatistik Yıllığı 1960-1962, Yayın No: 460, Ankara: İGM Yayınları.

TBMM Zabıt Cerideleri (1968), Cumhuriyet Senatosu Tutanak Dergisi, Ankara: TBMM Basımevi.

Telif ve Tetkik Eserler

Aktaş, Elif (2020), "27 Mayıs Darbesi Sürecinde Ankara Olaylarından Iki Kesit: 29 Nisan ve 555k", Ağrı ibrahim Çeçen Üniversitesi, Sosyal Bilimler Enstitüsü Dergisi, 2020, 6 (2), 219-241. https://doi.org/10.31463/aicusbed.776497

TRT Geçmişten Geleceğe Bilgiler Belgeler, Cilt: III, (1997), Ankara: Aydoğdu Yayıncılık. 
Beceren, Ertan ve Koç, Mehmet (2016), "Habur Sınır Kapısının Bölge Üzerindeki Etkileri”, Yüzüncü Yıl Üniversitesi iktisadi ve Idari Bilimler Fakültesi Dergisi, 2 (Bahar). 82-101.

Boybeyi, Songül (2008), “Prof. Dr. Illhan Başgöz ile Söyleşi”, Toplum ve Demokrasi, 2 (3), 285-290.

Buçan, Nadir (2014), Belgesel ve Toplumsal Belgeci Fotoğrafı Walter Benjamin'le Okumak (Yayımlanmamış Yüksek Lisans Tezi), Atatürk Üniversitesi Sosyal Bilimler Enstitüsü, Radyo Televizyon ve Sinema Ana Bilim Dalı, Erzurum.

Çakırbaş, Ali ve Gönen, Illknur (2021), Aksaray Halkevi ve Faaliyetleri, Erciyes Akademi, 35 (1), 61-78.

Tekir, Süleyman (2019), “Erken Cumhuriyet Dönemi Türkiye'de Bulaşıcı Hastalıklarla Mücadele (19231930)”, Atatürk Üniversitesi, Türkiyat Araştırmaları Enstitüsü Dergisi, 65 (Mayıs-2019), 407-430.

Dindarzade, Abdurrahim (2015), Yaşar Kemal ve Fikret Otyam'da Urfa Sevdası, ŞURKAV Dergisi, 23 (8), 3-9.

Oral, Merter (2011), Toplumsal Belgeci Fotoğraf ve Fikret Otyam Örneği, İstanbul: Espas Yayınları.

Otyam, Fikret (1957), Ha Bu Diyar. Ankara: Dost Yayınevi.

Otyam, Fikret (1961), Gide Gide 3 Harran. Hoyrat, Mayın ve Itrıp, Ankara: Forum Kitabevi.

Otyam, Fikret (1966), Gide Gide 8 Oy Firat Asi Firat. Ankara: Dost Yayınevi.

Otyam, Fikret (1969a), Gide Gide 10 Can Pazarı. Ankara: Doğan Yayınevi.

Otyam, Fikret (1969b), Gide Gide 9 Kaymakam Babo. Ankara: Dost Kitabevi

Otyam, Fikret (1981), Adı Yemenidir. İstanbul: Ağaoğlu Yayınevi.

Otyam, Fikret (1982), Gide Gide 1-2-3 Toplu Basım. İstanbul: Adam Yayınları.

Otyam, Fikret (1987), Harran Koçaklaması. İstanbul: Boyut Yayınevi

Otyam, Fikret (1991a), Ağlama Anam. İstanbul: Gendaş Yayınevi.

Otyam, Fikret (1991b), Ey Samandağ Samandağ. i̇stanbul: Gerçek Sanat Yayınları.

Otyam, Fikret (1994b), 40 Yıl Önce 40 Yıl Sonra. Ankara: Ümit Yayıncılık.

Özer, Sevilay (2014), "Türkiye'de Trahomla Mücadele (1925-1945)”. Ankara Üniversitesi Türk Inkılâp Tarihi Enstitüsü Atatürk Yolu Dergisi, 54 (14), 121-152.

Süreli Yayınlar

“Belediye Reisimiz Reşit Akyüz’ün Açış Nutku”, Urfanınsesi Gazetesi, 17 Nisan 1953, Sayı: 182.

“Birecik Köprüsünün Resmi Küşadı Nasıl Geçti?”, Akgün Gazetesi,16 Nisan 1956, Sayı: 2397.

“Teknik ve Zirai Bilgiler”, Demokrat Gazetesi, 13 Ocak 1953, Sayı: 17.

Kabacalı, Alpay, "Başarılı Röportajları, Fotoğraf ve Resimleriyle Tanınan Gazeteci-Ressam: Fikret Otyam Anadolu'ya Sevdalı", Cumhuriyet Gazetesi, 4 Aralık 1989.

Otyam, Fikret (1994a) "40 Yıl Önce 40 Yıl Sonra Yazan Kâtibin Suçu Ne Mevlam Demiş Böyle Yaz"”, Milliyet Gazetesi, 10.05.1994.

Temelkuran, Ece, "70 Yaşına Basan Gazeteci ve Ressam Fikret Otyam’la Yaşlıı̆ıı”, Sevdalarını ve Geleceği Konuştuk Urfa, Ceylanlar ve Cennet Resimleri ", Yeni Gün Gazetesi, 3 Ocak 1996 
Ibrahim Halil TANIK | Serkan ŞENEL

Tezcanoğlu, Sercan, "Ben Doğuya Sevdalıyım”, Milliyet Gazetesi, 31 Mayıs 1998.

"Valimiz Durmadan Çalışıyor", Demokrat Urfa Gazetesi, 21 Şubat 1958, Sayı: 859.

Internet Kaynakları

http://www.medyaurfa.com/gundem/otyam-ailesi-urfa-ile-baglantisini-koparmiyor-h45903.html Erişim Tarihi: 02.04.2018

http://bianet.org/biamag/bianet/1808-fikret-otyam-kutuphanesini-acti erişim tarihi: 02.04.2018.

https://fikretotyam.com/biyografi Erişim Tarihi: 21.04.2021

https://www.aa.com.tr/tr/turkiye/turk-halk-bilimci-prof-dr-ilhan-basgoz-vefat-etti/2208083 Erişim Tarihi: 22.04.2021 


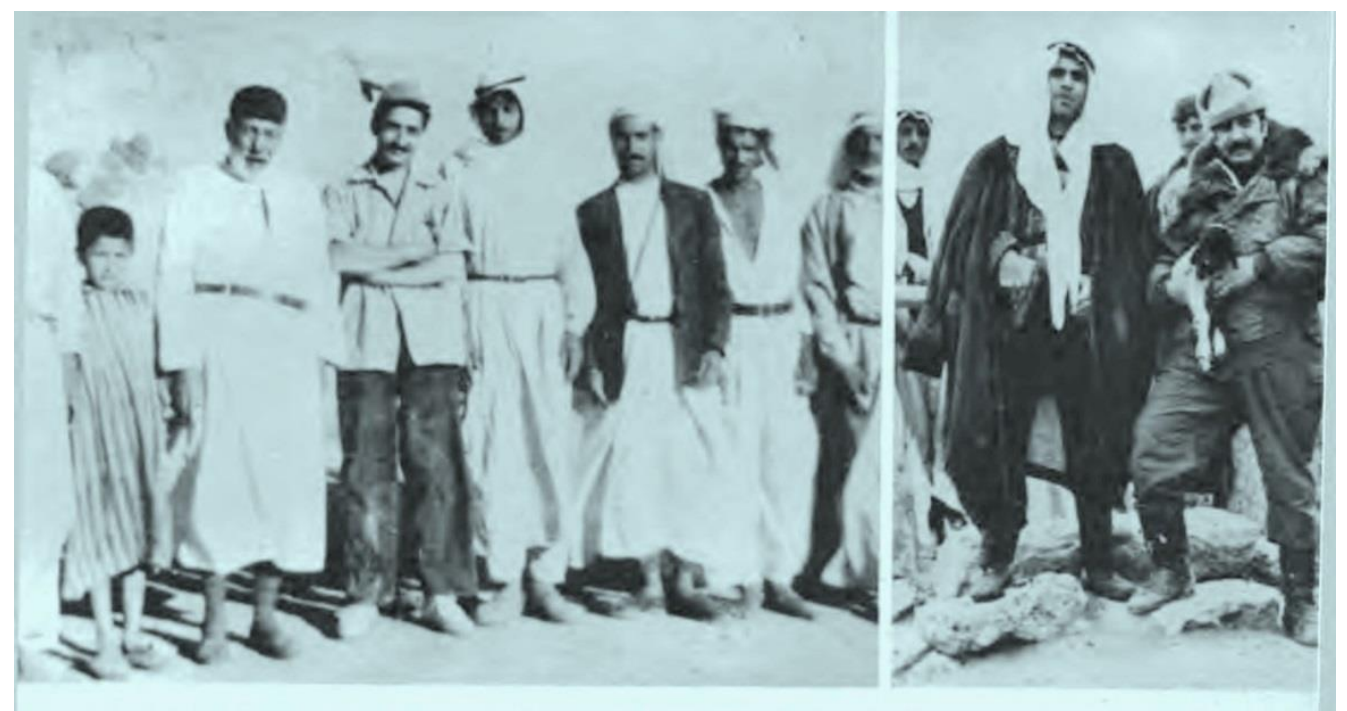

(Kaynak: Fikret Otyam, Gide Gide 10, s.228 ) Fikret Otyam Harranlılarla (Soldan Üçüncü Kişi)

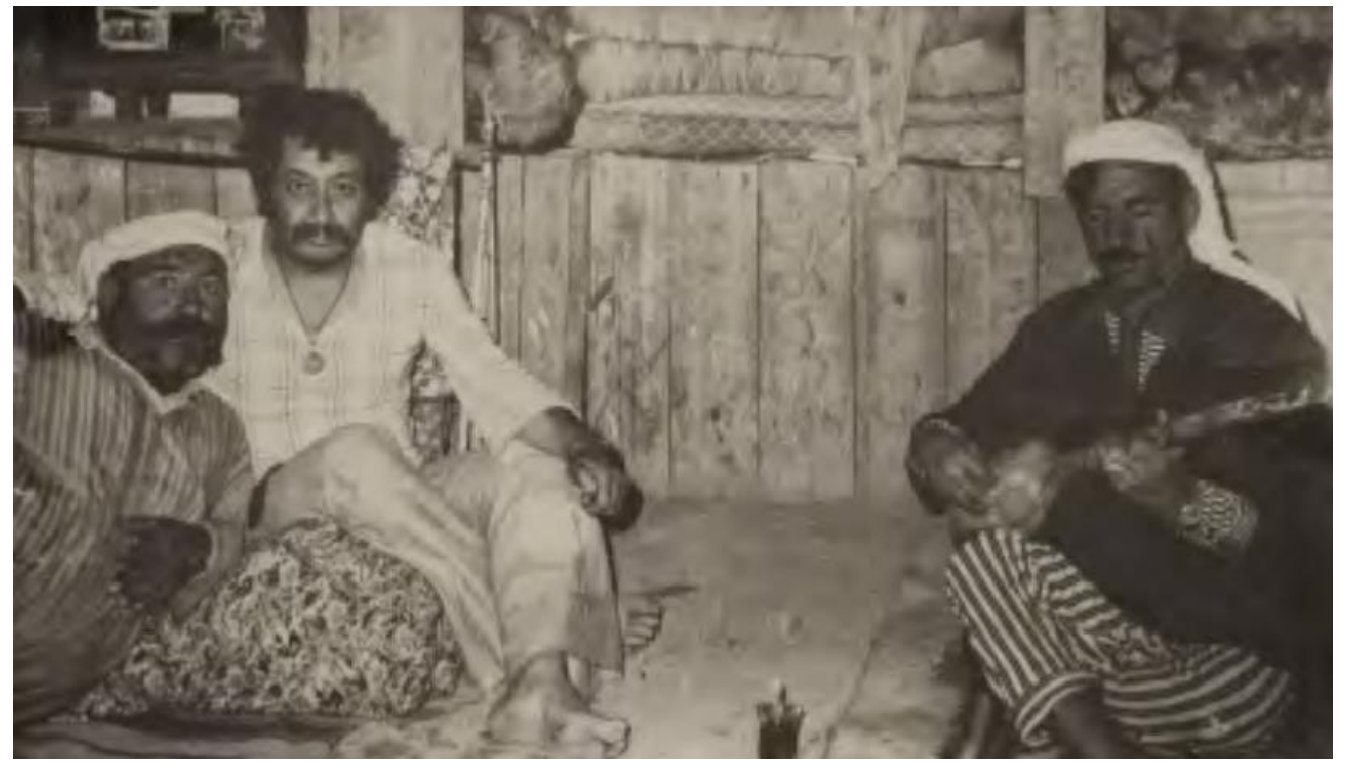

(Kaynak: Abdurrahim Dindarzade, "Yaşar Kemal ve Fikret Otyam'da Urfa Sevdası”, s. 8.) Soldan Sağa, Mehmet Kaya, Fikret Otyam, Veli Göncü. Kısas/1961. 
İbrahim Halil TANIK | Serkan ŞENEL

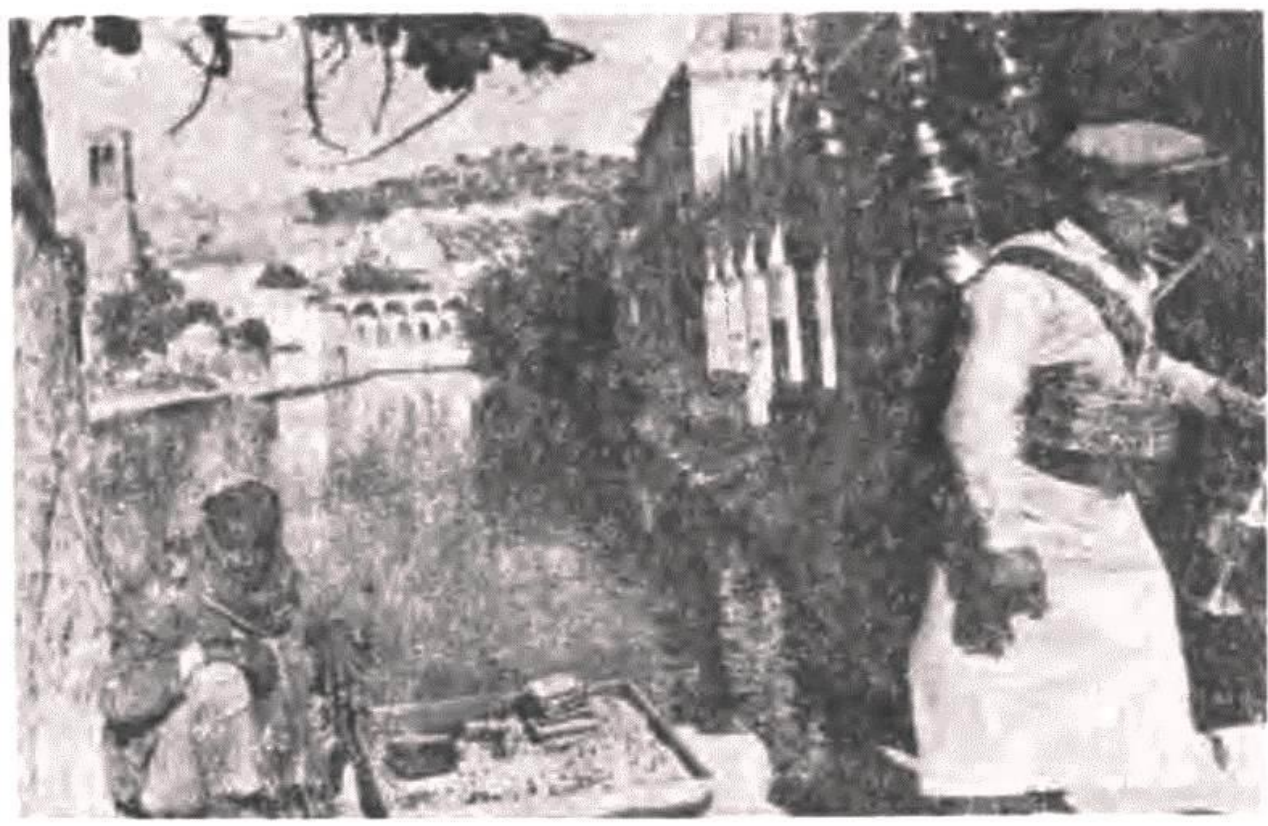

(Kaynak: Fikret Otyam, Gide Gide 1-2-3, s. 245)

Fikret Otyam'ın Makinesinden Balıklıgöl

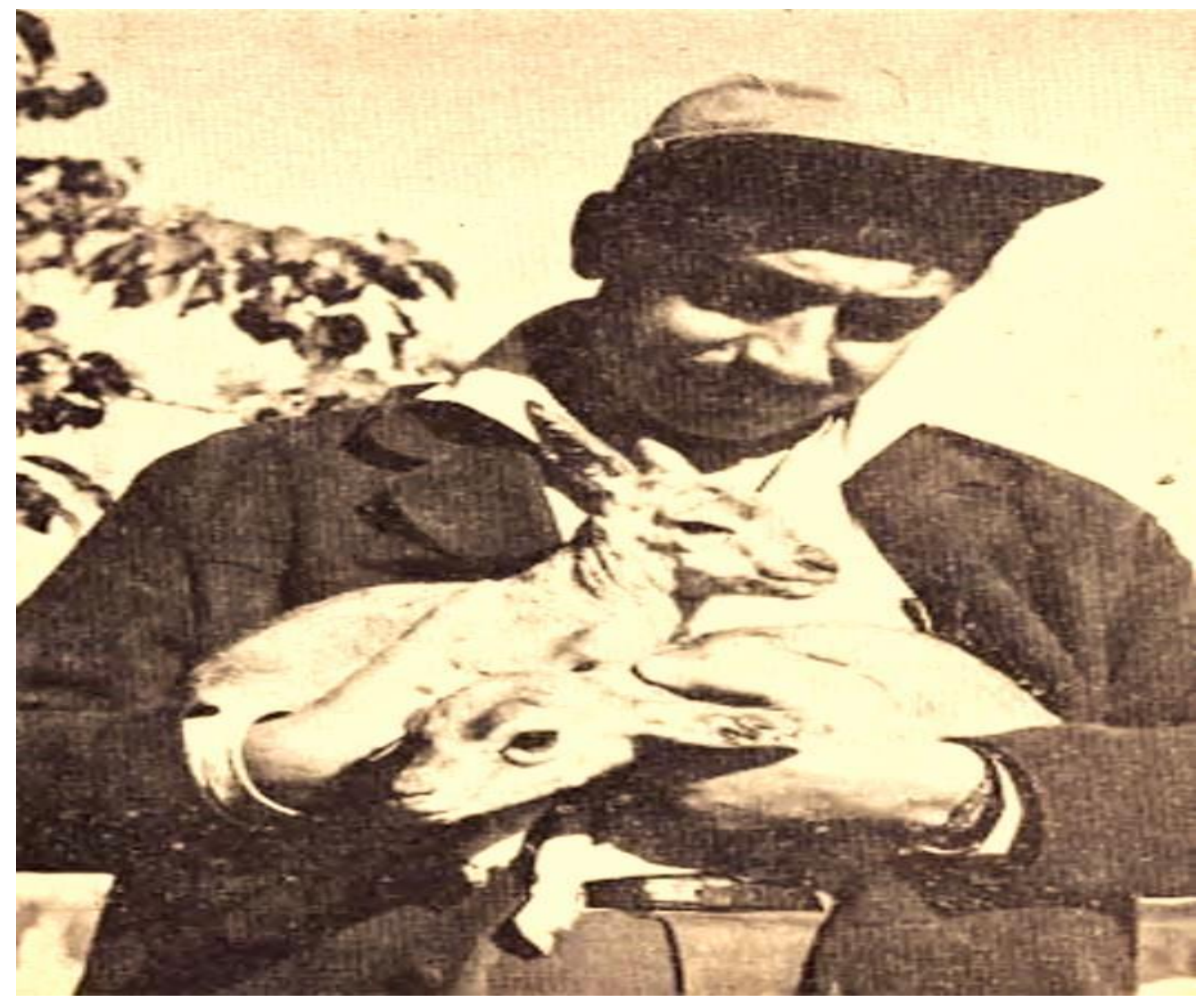

(Kaynak: Fikret Otyam, Gide Gide 3, s. 38)

Fikret Otyam Çok Sevdiği Ceylanlarla 


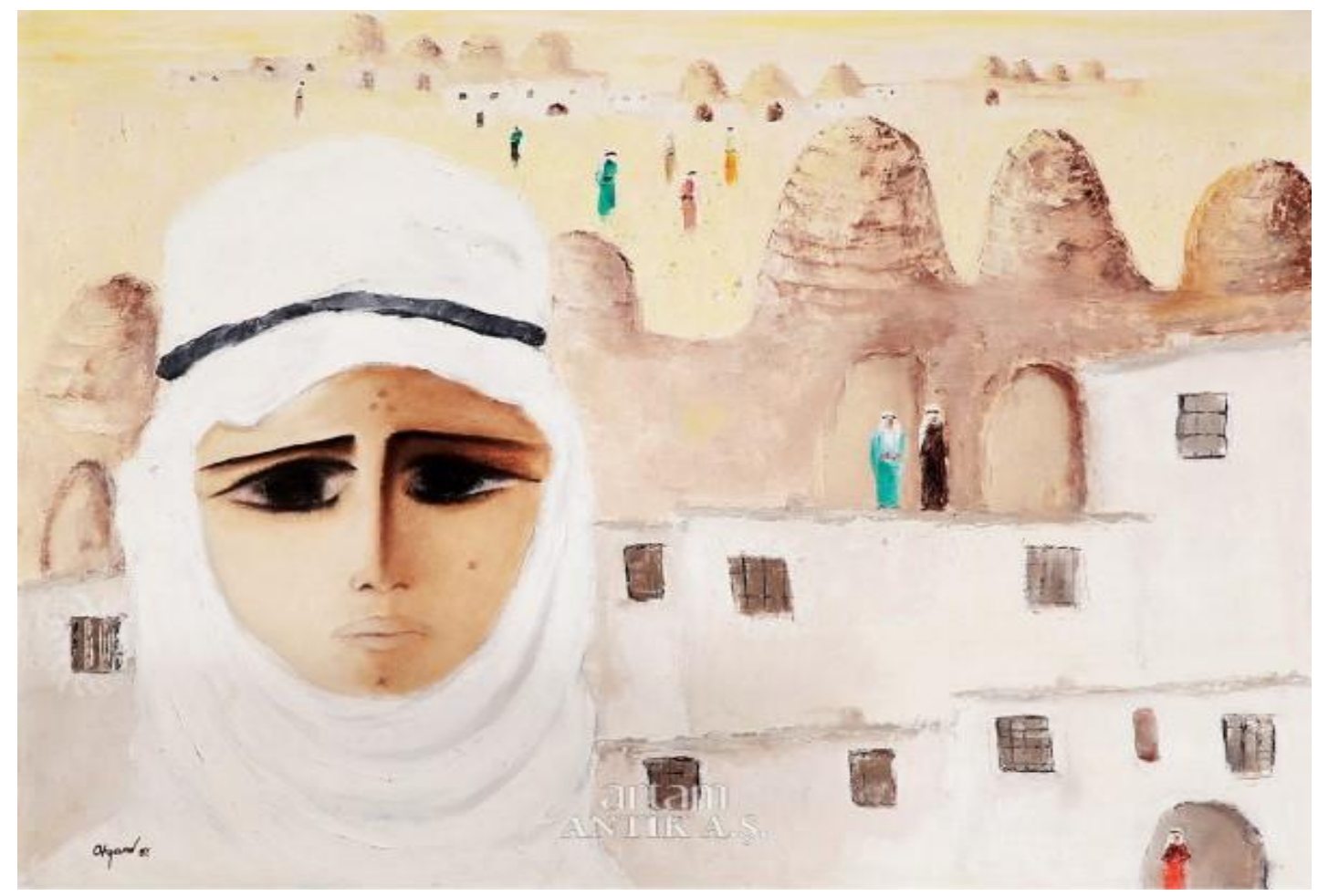

(Kaynak: https://artam.com/muzayede/305-muzayede-cagdas-sanat-eserleri-2/fikret-otyam-19262015-koylu-kadini-2 Erişim Tarihi: 28.04.2021)

Fikret Otyam'ın Resmettiği Harran ve Harranlı Kadın.

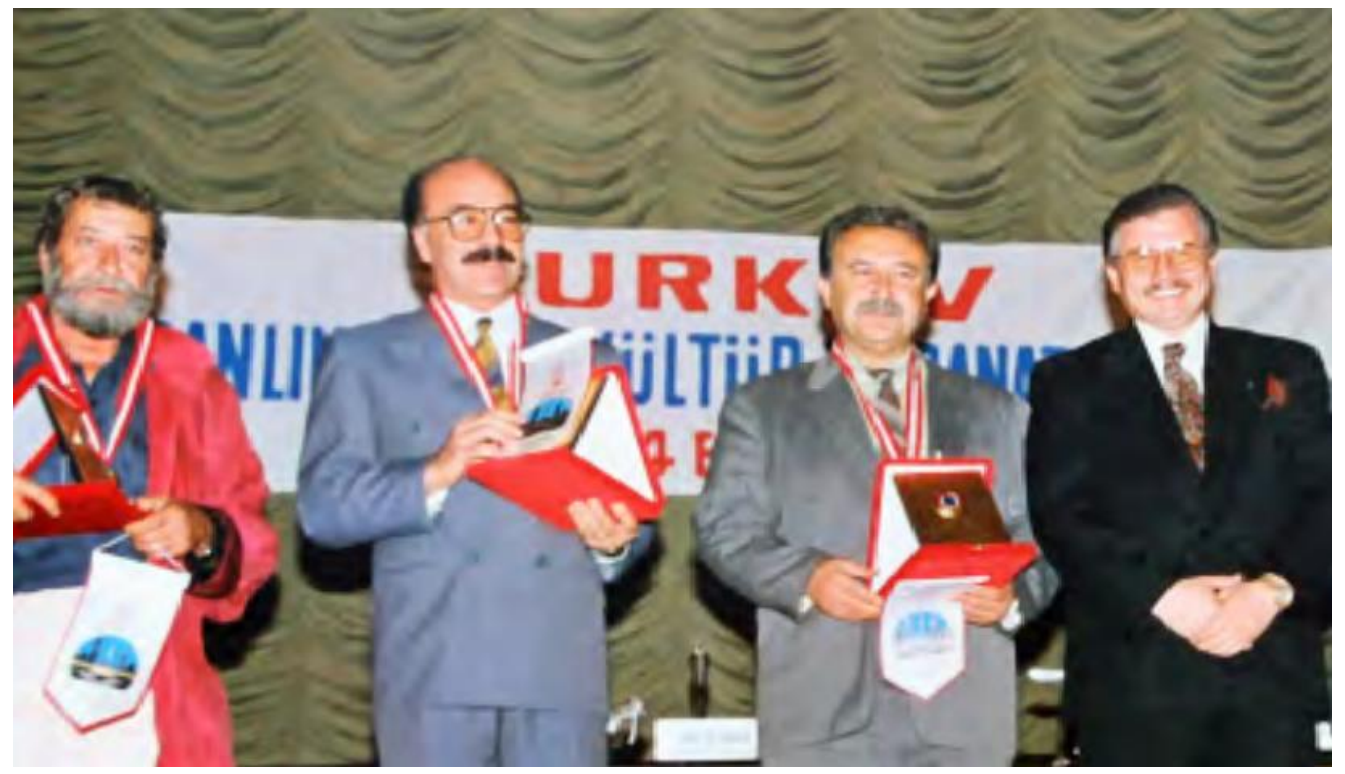

(Kaynak; Abdurrahim Dindarzade, "Yaşar Kemal ve Fikret Otyam'da Urfa Sevdası", s. 9.)Soldan Sağa, Fikret Otyam, Mehmet Özbek, Abdullah Balak, Ziyaettin Akbulut. ŞURKAV Tarafından Verilen Ödül Töreni. 